\title{
Acetylene as an Inhibitor of Methanogenic Bacteria
}

\author{
By G. D. SPROTT, ${ }^{1 *}$ K. F. JARRELL, ${ }^{1}$ K. M. SHAW ${ }^{1}$ AND R. KNOWLES ${ }^{2}$ \\ ${ }^{1}$ Division of Biological Sciences, National Research Council of Canada, Ottawa, \\ Ontario K1A OR6, Canada \\ ${ }^{2}$ Department of Microbiology, Macdonald Campus of McGill University, Ste Anne de Bellevue, \\ Quebec H9X 1CO, Canada
}

(Received 16 December 1981; revised 10 March 1982)

\begin{abstract}
Growth of six pure cultures of methanogens was inhibited by low concentrations of dissolved acetylene $\left(\mathrm{C}_{2} \mathrm{H}_{2}\right)$; other archaebacteria (three Halobacterium species) and several eubacteria were not similarly affected. The minimum concentration of dissolved $\mathrm{C}_{2} \mathrm{H}_{2}$ required to inhibit growth of Methanospirillum hungatei completely was about $8 \mu \mathrm{M}$; dissolved ethylene at $20 \mu \mathrm{M}$ had little effect on growth. Dissolved acetylene $(33 \mu \mathrm{M})$ did not alter the $E_{\mathrm{h}}$ of the medium, or result in a loss in viability of $M$. hungatei after $16 \mathrm{~h}$ exposures. In anaerobic cell extracts of $M$. hungatei, activities of hydrogenase, NADP reductase, methyl-coenzyme $M$ reductase and ATP hydrolase were not inhibited by $\mathrm{C}_{2} \mathrm{H}_{2}$ concentrations several times higher than those required for growth inhibition. The intracellular ATP content of all of the methanogens dropped dramatically on exposure to $\mathrm{C}_{2} \mathrm{H}_{2}$. Moreover, cells of $M$. hungatei and Methanobacterium bryantii on exposure to $\mathrm{C}_{2} \mathrm{H}_{2}$ lost their ability to maintain a transmembrane $\mathrm{pH}$ gradient. We suggest that exposure to $\mathrm{C}_{2} \mathrm{H}_{2}$ results in a decline in methanogen functions which require a $\mathrm{H}^{+}$-flux, including ATP synthesis, $\mathrm{Ni}^{2+}$ uptake and methanogenesis.
\end{abstract}

\section{INTRODUCTION}

Use of the acetylene $\left(\mathrm{C}_{2} \mathrm{H}_{2}\right)$ reduction assay as a valid quantitative measure of $\mathrm{N}_{2}$-fixation depends on $\mathrm{C}_{2} \mathrm{H}_{2}$ serving solely as an inhibitor of nitrogenase activity. Often this criterion is not met by the test system, since $\mathrm{C}_{2} \mathrm{H}_{2}$ can interact in some cases at other sites. For example, growth of nitrogenase-repressed Clostridium pasteurianum proved sensitive to $\mathrm{C}_{2} \mathrm{H}_{2}$ (Brouzes \& Knowles, 1971). Also, $\mathrm{C}_{2} \mathrm{H}_{2}$ served as a competitive inhibitor of $\mathrm{CH}_{4}$ oxidation by methylotrophs and inhibited the growth of several bacteria normally capable of growth on lower molecular weight hydrocarbons (deBont \& Mulder, 1976). Furthermore, the nitrous oxide reductase of several denitrifying bacteria (Balderston et al., 1976; Yoshinari \& Knowles, 1976), and ammonia oxidation to nitrite in Nitrosomonas europaea (Hynes \& Knowles, 1978) were sensitive to $\mathrm{C}_{2} \mathrm{H}_{2}$. At high $\mathrm{C}_{2} \mathrm{H}_{2}$ concentrations of 4 to $30 \%(\mathrm{v} / \mathrm{v})$ in the gas phase, inhibition of hydrogen uptake was observed in Azospirillum brasiliense (Chan et al., 1980), Azotobacter chroococcum (Smith et al., 1976) and several cyanobacteria (Bothe et al., 1977; Lambert \& Smith, 1980). Finally, the reversible hydrogenase of Klebsiella pneumoniae was also sensitive to inhibition by acetylene (Smith et al., 1976).

In view of the observed inhibition of hydrogenase activity described above, and the fact that, with few exceptions, methanogenic bacteria require $\mathrm{H}_{2}$ for growth (Zehnder et al., 1980), it seemed reasonable that methanogens should be sensitive to $\mathrm{C}_{2} \mathrm{H}_{2}$. Indeed, methanogenesis was inhibited by $\mathrm{C}_{2} \mathrm{H}_{2}$ in anaerobic sediments (Macgregor \& Keeney, 1973; Oremland \& Taylor, 1975), anaerobic paddy soils (Raimbault, 1975) and rumen fluid (Elleway et al., 1971). We now show for several pure cultures of methanogens that $\mathrm{C}_{2} \mathrm{H}_{2}$ does not interfere with hydrogenase activity, but with membrane events linked to proton movement and ATP synthesis.

\section{METHODS}

Micro-organisms and growth. Cultures of methanogens were obtained from sources already described (Sprott $e t$ al., 1979). Synthetic anaerobic media were prepared and dispensed in $10 \mathrm{ml}$ or $100 \mathrm{ml}$ amounts in vessels closed 
with butyl rubber stoppers (Sprott \& Jarrell, 1981). Bacteria were grown with a $\mathrm{CO}_{2} / \mathrm{H}_{2}$ gas phase in the $\mathrm{S}$ medium of Breuil \& Patel (1980), with the exceptions that Methanospirillum cultures required acetate (25 mM) and Methanobacterium bryantii medium contained additional phosphate, nickel, molybdenum, and $\mathrm{NH}_{4}-\mathrm{N}$ (Jarrell et al., 1982). Daily replenishment of the $\mathrm{CO}_{2} / \mathrm{H}_{2}$ gas atmosphere and the other growth conditions were as described by Sprott \& Jarrell (1981). Other cultures were obtained from the culture collection of the National Research Council of Canada. Halobacterium cutirubrum (NRCC 34001), H. halobium (NRC 34003) and H. salinarium (NRC 34002) were grown in the medium of Seghal \& Gibbons (1960); Escherichia coli SP10 in medium 63 (Prasad \& Schaefler, 1974) containing glycerol $(0.4 \%, \mathrm{v} / \mathrm{v})($ Cohen \& Rickenberg, 1956) and Casamino acids $(0.02 \% \mathrm{w} / \mathrm{v}) ;$ Clostridium pasteurianum (NRC 2485) in Reinforced Clostridial Medium (Oxoid) containing $340 \mu \mathrm{g} \mathrm{N} \mathrm{ml}^{-1}$ as $\left(\mathrm{NH}_{4}\right)_{2} \mathrm{SO}_{4}$; Desulfovibrio desulfuricans (NRC 49001, ATCC 7757) in medium N of Saunders et al. (1964) reduced with $1 \mathrm{mM}$ sodium sulphide plus $1.6 \mathrm{mM}$-cysteine; and Arthrobacter globiformis (NRC 32001) in Nutrient Broth (Difco). Anaerobic media were boiled under a $\mathrm{CO}_{2} / \mathrm{H}_{2}$ gas atmosphere $(1: 4, \mathrm{v} / \mathrm{v}$; Union Carbide Canada) for $C$. pasteurianum or $\mathrm{N}_{2}$ for $D$. desulfuricans, and $10 \mathrm{ml}$ samples dispensed into $120 \mathrm{ml}$ serum bottles (closed with butyl rubber stoppers) containing the respective gas phase. All cultures were grown at $35^{\circ} \mathrm{C}$ with shaking, except for Methanobacterium thermoautotrophicum which was grown at $62{ }^{\circ} \mathrm{C}$. Before use, the $\mathrm{CO}_{2} / \mathrm{H}_{2}$ gas mixture was passed through copper filings $\left(350^{\circ} \mathrm{C}\right)$ to remove possible traces of oxygen.

Gas chromatography. Methane, $\mathrm{C}_{2} \mathrm{H}_{2}$ and $\mathrm{C}_{2} \mathrm{H}_{4}$ were separated on a Porapak $\mathrm{T}$ column using the conditions described by Jarrell et al. (1982).

Intracellular ATP concentrations. Methanogens grown in $100 \mathrm{ml}$ cultures (analysed when half-way through the exponential phase, as determined by $A_{600}$ ) were dispensed in $10 \mathrm{ml} \mathrm{samples} \mathrm{into} 120 \mathrm{ml}$ serum bottles containing $\mathrm{CO}_{2} / \mathrm{H}_{2}(1: 4, \mathrm{v} / \mathrm{v})$. Various amounts of acetylene (Union Carbide Canada; $99.5 \%$ purity) were injected with an air-tight Hamilton syringe through the serum stoppers and incubation continued with shaking at the growth temperature for the test organism. Periodically, $1.0 \mathrm{ml}$ samples were withdrawn anaerobically by syringe and injected into $1.0 \mathrm{ml}$ ice-cold $12 \%(\mathrm{v} / \mathrm{v}) \mathrm{HClO}_{4}$. After $30 \mathrm{~min}$ the solution was carefully neutralized with $0.72 \mathrm{M}$ $\mathrm{KOH}$ and $0.16 \mathrm{M}-\mathrm{KHCO}_{3}$. ATP was measured in $1.0 \mathrm{ml}$ reaction mixtures containing a luciferin-luciferase preparation (Worthington Biochemical Corp., Freehold, N.J., U.S.A.) and $10 \mu \mathrm{l}$ cell extract. Quenching of about $18 \%$ was corrected for by including $10 \mu \mathrm{l}$ of an extract of growth medium in reaction mixtures containing known amounts of ATP. Intracellular ATP was calculated on the basis of cell dry weight. For Methanospirillum hungatei the cytoplasmic volume was determined as $2.01 \mu \mathrm{l}\left(\mathrm{mg}\right.$ dry wt cells) ${ }^{-1}$ (Sprott \& Jarrell, 1981), thus allowing calculation of the internal concentration of ATP.

Penetration of labels. Penetration of $\left[{ }^{14} \mathrm{C}\right]$ sucrose and $\left[{ }^{14} \mathrm{C}\right] \mathrm{glucose}$ into anaerobic methanogen suspensions was as described by Sprott \& Jarrell (1981). Similarly, methods to measure the accumulation of the weak acid 5,5dimethyl-2,4-oxazolidinedione (DMO) for calculation of intracellular $\mathrm{pH}\left(\mathrm{pH}_{\mathrm{i}}\right)$ of methanogens have been reported (Jarrell \& Sprott, 1981). Briefly, for accumulation of DMO, the bacteria were centrifuged anaerobically, the pellets resuspended in $17 \mathrm{mM}$-citrate $/ 44 \mathrm{mM}$-sodium phosphate buffer ( $\mathrm{pH} \mathrm{6.0)}$ prereduced with cysteine $(1.27 \mathrm{mM})$ plus sodium sulphide $(0.83 \mathrm{mM})$, and $5 \mathrm{ml}$ samples of the bacterial suspension were dispensed into $120 \mathrm{ml}$ serum bottles under a $\mathrm{CO}_{2} / \mathrm{H}_{2}$ gas phase $(1: 4, \mathrm{v} / \mathrm{v})$. After incubation with or without $\mathrm{C}_{2} \mathrm{H}_{2}$ for $4 \mathrm{~h}$ at $35^{\circ} \mathrm{C}$ with shaking, $\left[{ }^{14} \mathrm{C}\right] \mathrm{DMO}$ was injected. Following a $20 \mathrm{~min}$ incubation, the contents of each bottle were transferred anaerobically by syringe into an anaerobic glass centrifuge tube and immediately centrifuged $(10000 \mathrm{~g}, 10 \mathrm{~min}$, $25^{\circ} \mathrm{C}$ ). The distribution of DMO between the cell pellet and supernatant was determined and $\mathrm{pH}_{\mathrm{i}}$ calculated (Jarrell \& Sprott, 1981).

Uptake of ${ }^{63} \mathrm{Ni}$. Samples $(20 \mathrm{ml}$ ) of exponential phase Methanospirillum hungatei $\mathrm{GP} 1$, grown in $100 \mathrm{ml}$ culture to $0.35 \mathrm{mg}$ dry weight $\mathrm{ml}^{-1}$, were dispensed with plastic disposable syringes (flushed with $\mathrm{CO}_{2} / \mathrm{H}_{2}$ ) into $120 \mathrm{ml}$ serum vials under $\mathrm{CO}_{2} / \mathrm{H}_{2}(1: 4, \mathrm{v} / \mathrm{v})$. The experiment was started by addition of $\mathrm{C}_{2} \mathrm{H}_{2}(0 \cdot 2 \mathrm{ml})$ to the vials which were incubated at $35^{\circ} \mathrm{C}$, with shaking. Samples were removed anaerobically to determine the ATP concentration and for ${ }^{63} \mathrm{Ni}$ uptake measurements. For ${ }^{63} \mathrm{Ni}$ uptake, $25 \mu 1^{63} \mathrm{NiCl}_{2}\left[1.6 \mu \mathrm{M}, 629 \mu \mathrm{Ci}_{\mu \mathrm{mol}^{-1}}\left(23.27 \mathrm{MBq} \mu \mathrm{mol}^{-1}\right)\right.$; New England Nuclear Canada, Quebec] was added to $2.5 \mathrm{ml}$ cell suspension in a $60 \mathrm{ml}$ serum bottle under a $\mathrm{CO}_{2} / \mathrm{H}_{2}$ gas atmosphere $(1: 4, \mathrm{v} / \mathrm{v})$. Uptake, which was linear for at least $15 \mathrm{~min}$, was terminated by filtering $1.0 \mathrm{ml}$ samples through $0.45 \mu \mathrm{m}$ HA filters (Millipore). Filters were washed with $5 \mathrm{ml} 10 \mathrm{~mm}$-potassium phosphate buffer ( $\mathrm{pH} 7 \cdot 0$ ), and counted in Aquasol (New England Nuclear). ${ }^{63} \mathrm{Ni}$ uptake was very similar when the filter assay was compared to anaerobic centrifugation with correction for extracellular ${ }^{63} \mathrm{Ni}$ present in the cell pellet (Sprott \& Jarrell, 1981). Dry weights were determined by washing the cells with water and drying the cell pellet at $62^{\circ} \mathrm{C}$ to a constant weight.

Cell viability of Methanospirillum hungatei. The number of methanogen cells which remained viable after exposure to $\mathrm{C}_{2} \mathrm{H}_{2}$ was determined by colony counts. The appropriate liquid medium containing $1.5 \%(w / v)$ agar was prereduced and, while still liquid, $10 \mathrm{ml}$ samples were dispensed into $120 \mathrm{ml}$ serum bottles as for liquid medium preparation. Bacterial culture dilutions were made in serum bottles which contained prereduced liquid medium at $23^{\circ} \mathrm{C}$. Volumes $(0.4 \mathrm{ml})$ of the appropriate dilutions were mixed with prereduced growth medium containing $0.6 \%(\mathrm{w} / \mathrm{v})$ agar $\left(3 \mathrm{ml}, 46^{\circ} \mathrm{C}\right)$ and $0.6 \mathrm{ml}$ was added anaerobically to the solidified medium as an overlay. Colonies were counted after $14 \mathrm{~d}$ incubation at $35^{\circ} \mathrm{C}$. 
Oxidation-reduction potential. The $E_{\mathrm{h}}$ of methanogen media was determined with a platinum electrode as described by Patel \& Agnew (1981).

Cofactor preparation. $\mathrm{F}_{420}$ is a fluorescent compound synthesized by methanogens and apparently serving in vivo as the coenzyme for several oxidation-reduction reactions (Gunsalus \& Wolfe, 1980). $F_{420}$ was isolated from Methanospirillum hungatei (McKellar et al., 1981). Extracts of Methanospirillum hungatei were used to prepare component B as described by Gunsalus \& Wolfe (1980). Methyl-coenzyme $\mathrm{M}$ was prepared from $\mathrm{CH}_{3} \mathrm{I}$ and 2mercaptoethanesulphonic acid (Pierce Chemical Co., Rockford, Ill., U.S.A.) according to Gunsalus et al. (1978).

Preparation of bacterial extracts. Hydrogenase, NADP ${ }^{+}$reductase and methyl-coenzyme $\mathrm{M}$ reductase were measured in anaerobic spheroplast lysates of Methanospirillum hungatei (Sprott et al., 1979). Methanospirillum hungatei GP1 grown to late-exponential phase as a $100 \mathrm{ml}$ culture was harvested anaerobically under $\mathrm{N}_{2}$ (Sprott \& Jarrell, 1981). Cells were washed once with anaerobic $50 \mathrm{~mm}$-potassium phosphate buffer (pH 6.8) (prepared by boiling under $\mathrm{N}_{2}$, adding cysteine/sodium sulphide and dispensing in serum bottles as for growth medium preparation) and were resuspended in $5 \mathrm{ml}$ of this buffer containing $10 \mathrm{mg}$ dithiothreitol; sufficient $\mathrm{NH}_{4} \mathrm{OH}$ was added to raise the $\mathrm{pH}$ to $9 \cdot 0$. As judged by phase-contrast microscopy, more than $90 \%$ of the cells lysed within $30 \mathrm{~min}$. The $\mathrm{pH}$ was readjusted to $7 \cdot 0$ by injecting $\mathrm{HCl}$ through the serum stopper and $1 \mathrm{mg}$ DNAase-I was added (Worthington Biochemical Corp.). Extracts were stored in serum bottles under $\mathrm{H}_{2}$ or $\mathrm{N}_{2}$ by immersion in liquid nitrogen, or used within several hours of preparation. Protein was estimated with the Bio-Rad dye binding assay reagent, using bovine serum albumin as standard.

Hydrogenase. The reaction mixture $(2 \mathrm{ml})$, in spectrophotometer cuvettes flushed with $\mathrm{H}_{2}$, consisted of $100 \mu \mathrm{mol}$ phosphate buffer ( $\mathrm{pH} \mathrm{6.8)}$ reduced with cysteine/sulphide, and either $\mathrm{F}_{420}$ sufficient to give an $\boldsymbol{A}_{420}$ ( $1 \mathrm{~cm}$ path length) of 0.7 or benzylviologen $(1 \mu \mathrm{mol})$. Anaerobic extract was injected through the rubber stopper to start the reaction. Reaction rates were recorded at $23^{\circ} \mathrm{C}$ at $420 \mathrm{~nm}\left(\mathrm{~F}_{420}\right)$ or $578 \mathrm{~nm}$ (benzylviologen). To determine $\mathrm{C}_{2} \mathrm{H}_{2}$ effects, the enzyme preparation was preincubated with $\mathrm{C}_{2} \mathrm{H}_{2}$ for $1 \mathrm{~h}$ followed by injection into the assay mixture, which contained the same $\mathrm{C}_{2} \mathrm{H}_{2}$ concentration as used in the preincubation.

Methyl-coenzyme $\mathrm{M}$ reductase. $\mathrm{H}_{2}$-dependent formation of $\mathrm{CH}_{4}$ was measured in small (2.1 $\left.\mathrm{ml}\right)$ serum bottles (Gunsalus \& Wolfe, 1980). The reaction mixture $(0.5 \mathrm{ml})$ consisted of $17 \mu \mathrm{mol}$ potassium phosphate buffer (pH 6.8) prereduced with cysteine/sulphide, $10 \mu \mathrm{mol} \mathrm{Mg}^{2+}, 2 \mu \mathrm{mol} \mathrm{ATP,} 20 \mathrm{nmol} \mathrm{F}_{420}, 10 \mu \mathrm{l}$ component B preparation, $2 \mu \mathrm{mol}$ methyl-coenzyme $\mathrm{M}$ and $0.5 \mathrm{mg}$ (protein) spheroplast lysate. The reaction components under $\mathrm{N}_{2}$ were incubated at $35^{\circ} \mathrm{C}$ for $10 \mathrm{~min}$ to consume endogenous $\mathrm{C}_{1}$ units (Ellefson \& Wolfe, 1980), methylcoenzyme $M$ was added (and in some cases $\mathrm{C}_{2} \mathrm{H}_{2}$ ) and incubation continued under $\mathrm{H}_{2}$. Sampling of the gas phase $(100 \mu \mathrm{l})$ established that the rate of $\mathrm{CH}_{4}$ synthesis remained linear between the 0.5 and $1 \mathrm{~h}$ tests.

$F_{420}-N A D P^{+}$-reductase. An anaerobic assay $(2 \mathrm{ml})$ similar to that of Yamazaki et al. $(1980)$ was used. The assay $\left(\mathrm{N}_{2}\right)$ consisted of $95 \mu \mathrm{mol}$ prereduced potassium phosphate buffer $\left(\mathrm{pH} \mathrm{6.8)}, 10 \mu \mathrm{mol} \mathrm{Mg}{ }^{2+}, 20 \mathrm{nmol} \mathrm{F}_{420}\right.$ and $60 \mu \mathrm{g}$ spheroplast lysate protein. When required, $\mathrm{C}_{2} \mathrm{H}_{2}$ was added anaerobically as previously described. The reaction was initiated by injection of $1 \mu \mathrm{mol} \mathrm{NADP}{ }^{+}$. Reduction of $\mathrm{NADP}^{+}$was measured at $340 \mathrm{~nm}$ at $23^{\circ} \mathrm{C}$.

ATP hydrolase. A membrane fraction of Methanospirillum hungatei was prepared as described by Doddema $e t$ al. (1978). The reaction mixture $(1.0 \mathrm{ml})$ in $10 \mathrm{ml}$ serum bottles closed with butyl rubber seals contained $100 \mu \mathrm{mol}$ glycine $/ \mathrm{NaOH}$ buffer ( $\mathrm{pH} 8.0), 8 \mu \mathrm{mol} \mathrm{MgCl}_{2}$, extract (1.0 mg protein) and various amounts of $\mathrm{C}_{2} \mathrm{H}_{2}$. After $1 \mathrm{~h}$ at $35^{\circ} \mathrm{C}, 0.02 \%$ (w/v) Triton X-100 and $5 \mu \mathrm{mol}\left[\gamma^{-32} \mathrm{P}\right] \mathrm{ATP}$ (New England Nuclear) were added. Incubation continued for $20 \mathrm{~min}$, after which the reaction was stopped with cold $\mathrm{HClO}_{4}$ and unreacted ATP removed by adsorption on Norite A charcoal (Crane \& Lipmann, 1953). ${ }^{32} \mathrm{PO}_{4}$ released from ATP was counted in Aquasol. Boiled extract served as a blank.

$\mathrm{C}_{2} \mathrm{H}_{2}$ concentrations. Concentrations of $\mathrm{C}_{2} \mathrm{H}_{2}$ dissolved in the liquid phase were calculated according to Flett $e t$ al. (1976).

Cell growth. Growth was measured as $A_{600}$ in cuvettes of $1 \mathrm{~cm}$ path length. Resazurin in samples of culture media was reduced with dithionite before measurements were made.

\section{RESULTS}

Rates of growth and $\mathrm{CH}_{4}$ synthesis were similarly inhibited in cultures of Methanospirillum hungate i incubated with $\mathrm{C}_{2} \mathrm{H}_{2}$. Complete inhibition of growth and $\mathrm{CH}_{4}$ synthesis was found at $8 \mu \mathrm{M}-\mathrm{C}_{2} \mathrm{H}_{2}$ in the liquid phase (Fig. $1 \mathrm{a}$ ). No loss of $\mathrm{C}_{2} \mathrm{H}_{2}$ from the gas phase or formation of ethylene $\left(\mathrm{C}_{2} \mathrm{H}_{4}\right)$ was detected. The inhibition is specific to $\mathrm{C}_{2} \mathrm{H}_{2}$, since $\mathrm{C}_{2} \mathrm{H}_{4}$ at concentrations up to $20 \mu \mathrm{M}\left(0.45 \%, \mathrm{v} / \mathrm{v}\right.$, in the gas phase) had no effect on growth and only a small effect on $\mathrm{CH}_{4}$ synthesis (Fig. 1 b). Ethylene was similarly less inhibitory than $\mathrm{C}_{2} \mathrm{H}_{2}$ for methanogenesis in sediments, but did inhibit at high concentrations of 5 to $20 \%(\mathrm{v} / \mathrm{v})$ in the gas phase (Oremland \& Taylor, 1975).

Since oxygen is an inhibitor of the growth of methanogens, it was important to exclude it as a possible contaminant in the $\mathrm{C}_{2} \mathrm{H}_{2}$. Measurements of oxidation-reduction potential of the 


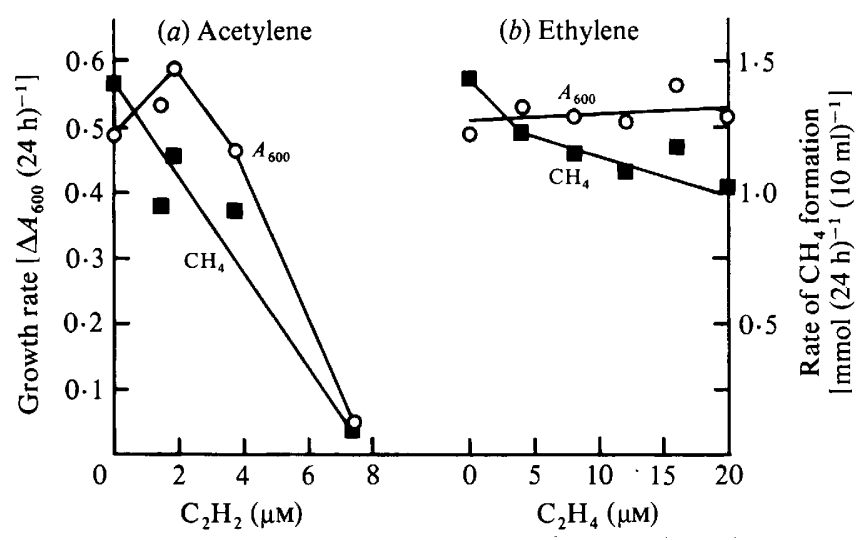

Fig. 1. Concentration dependence and specificity for acetylene inhibition of growth rate $(\mathrm{O})$, and methanogenesis ( $\square$ ). Results are shown for intact cells of Methanospirillum hungatei suspended in synthetic acetate medium $\left(E_{\mathrm{h}}-250 \mathrm{mV}\right)$. Rates were determined by taking readings during growth, with slopes taken from the linear portion of the curves.

medium $\left(E_{\mathrm{h}}\right.$ of $\left.-250 \mathrm{mV}\right)$ showed no effects of $\mathrm{C}_{2} \mathrm{H}_{2}$ at concentrations up to $650 \mu \mathrm{M}(2 \cdot 23 \mathrm{ml}$ added to a $120 \mathrm{ml}$ bottle containing $10 \mathrm{ml}$ of medium). Since, in separate experiments, at least $35 \mu \mathrm{O}_{2}$ was required to lower the $E_{\mathrm{h}}$ of the medium, the maximum $\mathrm{O}_{2}$ concentration present in the $\mathrm{C}_{2} \mathrm{H}_{2}$ could be $1.5 \%(\mathrm{v} / \mathrm{v})$. With $\mathrm{C}_{2} \mathrm{H}_{2}$ additions of $8 \mu \mathrm{M}$ this corresponds to a maximum amount of $\mathrm{O}_{2}$ of $0.4 \mu \mathrm{l}$, or between 25 - and 50 -fold less than was required to inhibit the growth of Methanospirillum hungatei. As a second approach, it was found that the oxygen-sensitive enzyme hydrogenase was not inhibited by large amounts of $\mathrm{C}_{2} \mathrm{H}_{2}$ (see below).

Exponential growth and maximum rates of $\mathrm{CH}_{4}$ synthesis occurred in control cultures between 24 and $48 \mathrm{~h}$ after inoculation. Since rates of growth and $\mathrm{CH}_{4}$ synthesis are reported from cultures in the exponential phase (Fig. 1), it follows that the inoculum had been exposed for at least $24 \mathrm{~h}$ to $\mathrm{C}_{2} \mathrm{H}_{2}$. Under these conditions the $\mathrm{CH}_{4}$ synthesis rate declined to $50 \%$ of the maximum when the dissolved $\mathrm{C}_{2} \mathrm{H}_{2}$ concentration was $4 \mu \mathrm{M}$ (Fig. $1 \mathrm{a}$ ). Cell suspensions of Methanospirillum hungatei exposed for shorter times of $1 \mathrm{~h}$ required a higher concentration of dissolved $\mathrm{C}_{2} \mathrm{H}_{2}(24 \mu \mathrm{M})$ to inhibit the $\mathrm{CH}_{4}$ synthesis rate by $50 \%$ (data not shown). Exposure of Methanospirillum hungatei to $65 \mu \mathrm{M}-\mathrm{C}_{2} \mathrm{H}_{2}$ for $16 \mathrm{~h}$, followed by colony counts in a $\mathrm{C}_{2} \mathrm{H}_{2}$-free medium, resulted in no loss of cell viability.

Methanospirillum hungatei cells exposed to $\mathrm{C}_{2} \mathrm{H}_{2}$ showed a decline in intracellular ATP concentration, and this depended on the concentration of $\mathrm{C}_{2} \mathrm{H}_{2}$ (Fig. 2). An exposure time of $8 \mathrm{~h}$ was required before the concentration of intracellular ATP approached very low values at the lower concentrations of dissolved $\mathrm{C}_{2} \mathrm{H}_{2}(15-20 \mu \mathrm{M})$. The decline in ATP content could thus explain inhibition in growth, because under these growth conditions Methanospirillum hungatei cultures undergo a lag phase of about $24 \mathrm{~h}$ (during which time $\mathrm{C}_{2} \mathrm{H}_{2}$ is present if required) before exponential growth proceeds, with a generation time in this experiment of $13 \mathrm{~h}$.

The decline in intracellular ATP concentration to less than $10 \%$ of that present in cultures of Methanospirillum hungatei not exposed to $\mathrm{C}_{2} \mathrm{H}_{2}$ suggested inhibition of ATP synthesis. To test whether $\mathrm{C}_{2} \mathrm{H}_{2}$ could interfere with the ability of the methanogen to maintain a transmembrane $\mathrm{H}^{+}$-gradient, the cells were harvested anaerobically and resuspended in anaerobic buffer of $\mathrm{pH} 6.0$. This external $\mathrm{pH}$ drop is necessary, since at $\mathrm{pH} 6.8$ there is no $\Delta \mathrm{pH}$ detectable in Methanospirillum hungatei and Methanobacterium thermoautotrophicum (Jarrell \& Sprott, 1981). This unusual property applies to Methanobacterium bryantii strain $\mathrm{MoH}$ as well, since DMO was equally distributed between the inside and outside of bacterial cells in growth medium of pH 6.95 (data not shown). Methanospirillum hungatei incubated in acidic buffer $\left(\mathrm{CO}_{2} / \mathrm{H}_{2} ; 1: 4\right.$, $\mathrm{v} / \mathrm{v}$ ) maintains only a small pH gradient (Jarrell \& Sprott, 1981), which is abolished during a $4 \mathrm{~h}$ exposure to $65 \mu \mathrm{M}-\mathrm{C}_{2} \mathrm{H}_{2}$ (Table 1). Also shown in Table 1 is the loss in ability of Methanobacterium bryantii to maintain a $\Delta \mathrm{pH}$ during exposure to acetylene. 


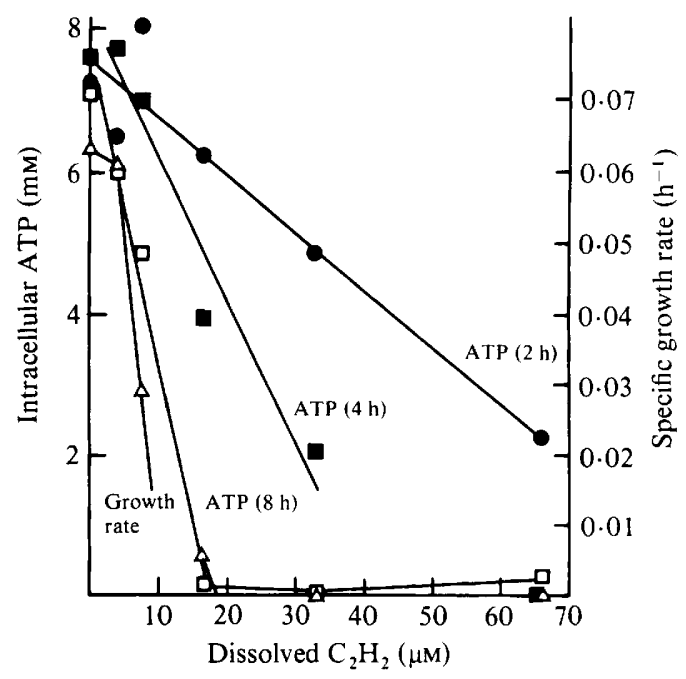

Fig. 2. Decline of intracellular ATP content of Methanospirillum hungatei, compared to the decline in growth rate. Intracellular ATP concentrations are shown following exposures to $\mathrm{C}_{2} \mathrm{H}_{2}$ of $2 \mathrm{~h}(\mathrm{O}), 4 \mathrm{~h}$ $(\square)$, and $8 \mathrm{~h}(\square)$. Specific growth rate $(\triangle)$ is defined as $\ln 2$. (mean doubling time) ${ }^{-1}$. No ATP was detected in the culture supernatants.

Table 1. Loss of ability of methanogens to maintain a pH gradient after exposure to acetylene

Methanospirillum hungatei or Methanobacterium bryantii were exposed to $\mathrm{C}_{2} \mathrm{H}_{2}$ for $4 \mathrm{~h}$ or $2 \mathrm{~h}$, respectively, in prereduced buffer at $\mathrm{pH} 6 \cdot 0$. Uptake of the weak acid $\left[{ }^{14} \mathrm{C}\right] \mathrm{DMO}$ was then determined. Mean values \pm S.E. are shown for duplicate $(M$. hungatei $)$ and triplicate $\left(M\right.$. bryantii) samples. $\mathrm{pH}_{i}$, internal $\mathrm{pH} ; \Delta \mathrm{pH}$, transmembrane $\mathrm{pH}$ difference.

Dissolved
$\mathrm{C}_{2} \mathrm{H}_{2}$ concn

$\mathrm{C}_{2} \mathrm{H}_{2}$ con
$(\mu \mathrm{M})$

$\begin{array}{ccc}(\mu \mathrm{M}) & \overbrace{\mathrm{pH}_{\mathrm{i}}} & \Delta \mathrm{pH} \\ 0 & 6.29 & 0.25 \pm 0.01 \\ 15 & 6.28 & 0.28 \pm 0.02 \\ 30 & 6.23 & 0.21 \pm 0.01 \\ 50 & 6.17 & 0 \cdot 17 \pm 0.01 \\ 65 & 6.00 & 0.00 \pm 0.05\end{array}$

M. hungatei
M. bryantii

$\begin{array}{cc}\mathrm{pH}_{\mathrm{i}} & \Delta \mathrm{pH} \\ 6.60 & 0.58 \pm 0.05 \\ \mathrm{ND} & \mathrm{ND} \\ \mathrm{ND} & \mathrm{ND} \\ \mathrm{ND} & \mathrm{ND} \\ 6.13 & 0.11 \pm 0.04\end{array}$

ND, not done.

The effect of $\mathrm{C}_{2} \mathrm{H}_{2}$ on various enzyme activities is shown in Table 2. Cell extracts were exposed for $1 \mathrm{~h}$ to concentrations of $\mathrm{C}_{2} \mathrm{H}_{2}$ at least 10 -fold higher than those giving a dramatic decline in intracellular ATP content after $2 \mathrm{~h}$ exposures (Fig. 2). None of the enzyme activities tested were inhibited significantly. As reported by Doddema et al. (1978) air did not inhibit ATP hydrolysis, since similar rates (and dependence on Triton X-100) were seen in anaerobic spheroplast lysates (data not shown).

Glucose and sucrose penetrated Methanospirillum hungatei cells to different degrees: this is thought to reflect barriers at the cytoplasmic membrane and inner cell wall (Sprott \& Jarrell, 1981). Exposure of Methanospirillum hungatei to $\mathrm{C}_{2} \mathrm{H}_{2}$ sufficient to abolish maintenance of $\Delta \mathrm{pH}$ did not render the cytoplasmic membrane permeable to glucose or sucrose (Table 3 ).

Methanospirillum hungatei cells take up ${ }^{63} \mathrm{Ni}$, which is incorporated into $\mathrm{F}_{430}$ (not shown) as described for Methanobacterium thermoautotrophicum (Diekert et al., 1980). ${ }^{63} \mathrm{Ni}$ uptake was only partially inhibited by $\mathrm{C}_{2} \mathrm{H}_{2}$, and inhibition occurred at a slower rate than did the decline in intracellular ATP concentration (Fig. 3).

The correlation between inhibition by $\mathrm{C}_{2} \mathrm{H}_{2}$ of growth of Methanospirillum hungatei and decline in cellular ATP content can be generalized to include other methanogens (Table 4). No loss of ATP to the medium occurred. Of the methanogens tested, the Methanobacterium species 


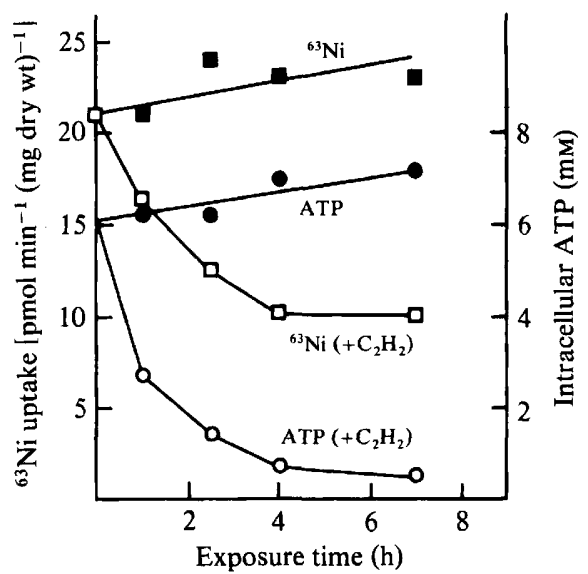

Fig. 3. Effect of dissolved acetylene $(65 \mu \mathrm{M})$ on ${ }^{63} \mathrm{Ni}$ uptake $(\square)$ into cultures of Methanospirillum hungatei. Intracellular ATP concentration $(\mathrm{O})$ is shown for comparison. ${ }^{63} \mathrm{Ni}$ uptake $(\mathbb{D})$ and ATP concentration (O) for control cells, which were incubated without $\mathrm{C}_{2} \mathrm{H}_{2}$, are shown also.

\section{Table 2. Effect of acetylene on selected enzymes of Methanospirillum hungatei}

Enzymes other than ATP hydrolase were measured in anaerobic spheroplast lysates. ATP hydrolase was assayed in aerobically prepared French pressure cell extracts. Exposures to $\mathrm{C}_{2} \mathrm{H}_{2}$ were for $1 \mathrm{~h}$ at $35^{\circ} \mathrm{C}$.

\begin{tabular}{|c|c|c|}
\hline Enzyme activity* & $\begin{array}{c}\text { Dissolved } \\
\mathrm{C}_{2} \mathrm{H}_{2} \text { concn } \\
(\mu \mathrm{M})\end{array}$ & $\begin{array}{l}\text { Specific activity } \\
{\left[\text { nmol min }{ }^{-1}\right.} \\
\left.(\mathrm{mg} \text { protein })^{-1}\right]\end{array}$ \\
\hline Hydrogenase $\left(\mathrm{H}_{2} \rightarrow \mathrm{F}_{420}\right)$ & $\begin{array}{r}0 \\
140 \\
710\end{array}$ & $\begin{array}{l}141 \\
106 \\
271\end{array}$ \\
\hline $\mathrm{NADP}^{+}$reductase & $\begin{array}{r}0 \\
710\end{array}$ & $\begin{array}{l}22 \\
25\end{array}$ \\
\hline Methyl-coenzyme $\mathbf{M}$ reductase & $\begin{array}{r}0 \\
950 \\
1900\end{array}$ & $\begin{array}{l}2 \cdot 1 \\
3 \cdot 6 \\
3 \cdot 4\end{array}$ \\
\hline ATP-hydrolase & $\begin{array}{r}0 \\
900 \\
3600\end{array}$ & $\begin{array}{l}16.6 \\
14.9 \\
14.7\end{array}$ \\
\hline
\end{tabular}

*Hydrogenase activity was shown to be dependent on $\mathrm{H}_{2}$. Maximum activity of methyl-coenzyme $\mathrm{M}$ reductase required methyl-coenzyme $\mathrm{M}, \mathrm{H}_{2}, \mathrm{~F}_{420}$ and cell-free extract as source of component $\mathrm{B}$. Triton X-100 was necessary in the assay mixture for detection of ATP hydrolase activity.

Table 3. Penetration of sucrose and glucose into Methanospirillum hungatei after exposure to acetylene

Labelled compounds were added after $4 \mathrm{~h}$ incubation with (or without) $130 \mu \mathrm{M}-\mathrm{C}_{2} \mathrm{H}_{2}$. Equilibration with the cytoplasm, without accumulation, corresponds to $100 \%$ penetration (gravimetric value).

\begin{tabular}{ccc}
$\begin{array}{c}\text { Dissolved } \\
\mathrm{C}_{2} \mathrm{H}_{2} \text { concn } \\
(\mu \mathrm{M})\end{array}$ & \multicolumn{2}{c}{ Sucrose } \\
0 & $72 \cdot 3$ & Glucose \\
130 & $73 \cdot 1$ & $80 \cdot 0$
\end{tabular}

were most sensitive, Methanospirillum hungatei intermediate, and Methanosarcina barkeri the least sensitive. Eubacteria and the archaebacteria represented by the extreme halophiles were resistant to dissolved $\mathrm{C}_{2} \mathrm{H}_{2}$ concentrations fivefold higher than those which inhibited the methanogens. However, higher concentrations of $\mathrm{C}_{2} \mathrm{H}_{2}$ may be inhibitory for growth as was shown for nitrogenase-repressed C. pasteurianum (Brouzes \& Knowles, 1971). 
Table 4. Effect of acetylene on various bacteria

The dissolved $\mathrm{C}_{2} \mathrm{H}_{2}$ concentration was $65 \mu \mathrm{M}$ for methanogens and $325 \mu \mathrm{M}$ for extreme halophiles and eubacteria.

\begin{tabular}{|c|c|c|c|c|}
\hline \multirow[b]{2}{*}{ Bacterium } & \multirow[b]{2}{*}{$\begin{array}{l}\text { Growth rate } \\
(\% \text { inhibition) }\end{array}$} & \multicolumn{3}{|c|}{$\begin{array}{l}\text { ATP content } \dagger \\
\text { ( } \% \text { decline })\end{array}$} \\
\hline & & $1 \mathrm{~h}$ & $\overbrace{3 h}$ & $5 \mathrm{~h}$ \\
\hline $\begin{array}{l}\text { Archaebacteria } \\
\text { Methanobacterium bryantii MoH } \\
\text { Methanobacterium thermoautotrophicum } \\
\text { Methanobacterium strain G2R } \\
\text { Methanosarcina barkeri } \\
\text { Methanospirillum hungatei JF1 } \\
\text { Methanospirillum hungatei } \mathrm{GP1} \\
\text { Halobacterium cutirubrum } \\
\text { H. halobium } \\
\text { H. salinarium }\end{array}$ & $\begin{array}{r}100 \\
100 \\
100 \\
82 \\
100 \\
100 \\
0 \\
1 \\
0\end{array}$ & $\begin{array}{r}100 \\
90 \\
96 \\
55 \\
54 \\
42 \\
\text { ND } \\
\text { ND } \\
\text { ND }\end{array}$ & $\begin{array}{r}100 \\
98 \\
100 \\
67 \\
58 \\
66\end{array}$ & $\begin{array}{r}100 \\
100 \\
100 \\
75 \\
71 \\
87\end{array}$ \\
\hline $\begin{array}{l}\text { Eubacteria } \\
\text { Arthrobacter globiformis } \\
\text { Escherichia coli } \\
\text { Clostridium pasteurianum* } \\
\text { Desulfovibrio desulfuricans* }\end{array}$ & $\begin{array}{l}0 \\
2 \\
0 \\
0\end{array}$ & $\begin{array}{l}\text { ND } \\
\text { ND } \\
\text { ND } \\
\text { ND }\end{array}$ & & \\
\hline
\end{tabular}

ND, Not determined.

* Repressed for nitrogenase by growth with $\mathrm{NH}_{4}-\mathrm{N}$.

$\dagger$ The ATP contents of methanogens not receiving $\mathrm{C}_{2} \mathrm{H}_{2}$ remained constant during the experiment and, in nmol ATP (mg protein) ${ }^{-1}$, were: Methanobacterium bryantii, 3.3; Methanobacterium thermoautotrophicum, 7.0; Methanobacterium strain G2R, 4.5; Methanosarcina barkeri, 3.2; Methanospirillum hungatei JF1, 22.6; and $M$. hungatei GP1, 20.0. Under these conditions of assay, the detection limit was about $0.2 \mathrm{nmol}$ ATP (mg protein $)^{-1}$.

\section{DISCUSSION}

Acetylene inhibits several functions in methanogens. Inhibition of growth and $\mathrm{CH}_{4}$ synthesis, and the decline in the intracellular ATP concentration, all show similar kinetics of inhibition dependent on the exposure time and concentration of $\mathrm{C}_{2} \mathrm{H}_{2}$ used. Inhibitions which require exposures of several hours to the low inhibitor concentrations suggest that penetration to the sensitive site(s) may be a rate-determining step, or that the rate of reaction between $\mathrm{C}_{2} \mathrm{H}_{2}$ and the site of inhibition is slow. In attempts to investigate the mechanism of inhibition further, we found that the ability of methanogens to maintain a small proton gradient at an acidic external $\mathrm{pH}$ of 6.0 (Jarrell \& Sprott, 1981) was greatly impaired by $\mathrm{C}_{2} \mathrm{H}_{2}$. Gross membrane damage did not occur, since the lack of penetration of glucose and sucrose past the cytoplasmic membrane of Methanospirillum hungatei remained unaltered after exposure to $\mathrm{C}_{2} \mathrm{H}_{2}$. This mode of inhibition by $\mathrm{C}_{2} \mathrm{H}_{2}$ seems limited so far to the methanogens. The growth of several extremely halophilic bacteria, which are taxonomically related to the methanogens (Woese et al., 1978), was not inhibited (Table 4).

The effect of $\mathrm{C}_{2} \mathrm{H}_{2}$ on intracellular ATP concentrations appears to result from interference in proton movements. A chemiosmotic mechanism appears to account for all of the ATP synthesized by methanogens. As evidence, synthesis of ATP was demonstrated following a rapid pH shift in Methanosarcina barkeri (Mountfort, 1978) and Methanobacterium thermoautotrophicum (Doddema et al., 1978). This synthesis was shown, in the case of Methanosarcina barkeri, to be inhibited by an ATPase inhibitor and by uncouplers (proton conductors). ATP is normally synthesized by methanogens in growth media of $\mathrm{pH} 6 \cdot 8-7 \cdot 0$, where the membrane potential is the principal component of the electrochemical proton gradient (Jarrell \& Sprott, 1981). This is possible, since Wilson et al. (1976) have shown net synthesis of ATP in E. coli in response to a membrane potential in the absence of a $\triangle \mathrm{pH}$. Acetylene caused a decline in intracellular ATP from methanogens with no loss of ATP into the growth media, and prevented the maintenance of a $\Delta \mathrm{pH}$ in cells suspended in anaerobic buffer of $\mathrm{pH} 6 \cdot 0$. These results suggest that ATP 
synthesis is inhibited through the effect of $\mathrm{C}_{2} \mathrm{H}_{2}$ on the flux of protons across a membrane.

An inability to maintain a transmembrane $\mathrm{pH}$ difference could be caused either by induced membrane leakiness to protons, or to inhibition of active proton extrusion from the cell. Although the proton pump of methanogens has not been identified, likely candidates are the hydrogenase $\left(\mathrm{F}_{420}\right.$-linked), where the proton gradient may exist between the cytosol and intracellular vesicles (Spencer et al., 1980), or through ATP hydrolysis (Mitchell, 1975). No evidence was found for inhibition of these theoretical proton pumps. However, more direct evidence is required to determine unequivocally whether proton extrusion from the cell or loss of membrane permeability to protons occurs. Because $\mathrm{C}_{2} \mathrm{H}_{2}$ stimulates hydrogenase activity (Table 2), some interaction or conformational change of the enzyme may have occurred to give a more active enzyme which no longer pumps protons.

Evidence is increasing to support the suggestion that $\mathrm{CO}_{2}$ reduction to $\mathrm{CH}_{4}$ occurs at the site of intracytoplasmic membranes, with energy input supplied by an energized membrane state (Spencer et al., 1980; Kell et al., 1981 a; Sauer et al., 1981). We believe the uptake of DMO which occurs into intact methanogen cells under appropriate conditions (Jarrell \& Sprott, 1981) reflects an $\mathrm{H}^{+}$-gradient across the cytoplasmic membrane (and not across the intracellular membranes). Firstly, at the $\mathrm{pH}$ of the growth medium where DMO uptake does not occur (Jarrell \& Sprott, 1981) the cells are still able to synthesize $\mathrm{CH}_{4}$ and ATP. Clearly, if these processes depend on a $\mathrm{pH}$ gradient across the intracytoplasmic membranes, this gradient is not detected by DMO uptake into intact cells. Secondly, if the intracytoplasmic membranes are acidic inside with respect to the cytoplasm, as suggested by Sauer et al. (1981), the weak acid DMO would not accumulate inside these vesicles. Finally, the inside volume of any intracytoplasmic vesicles would be relatively small compared to the cytoplasmic volume, making detection of this intravesicular $\mathrm{pH}$ gradient difficult. It is possible, however, that $\mathrm{C}_{2} \mathrm{H}_{2}$ can also abolish a $\Delta \mathrm{pH}$ across internal vesicles and thus account for inhibition of $\mathrm{CH}_{4}$ synthesis.

Uptake of $\mathrm{Ni}^{2+}$ by Methanospirillum hungatei was identified as an additional membrane event affected by $\mathrm{C}_{2} \mathrm{H}_{2}$. Although the energetics of $\mathrm{Ni}^{2+}$ transport in methanogens is unknown, the ion is essential to the growth of Methanobacterium thermoautotrophicum (Schönheit et al., 1979) and Methanobacterium bryantii (Jarrell et al., 1982).

Use of $\mathrm{C}_{2} \mathrm{H}_{2}$ to assess $\mathrm{N}_{2}$-fixing activity of a complex system, such as a water-logged soil, could result in inhibition of methanogens. This would be especially acute at the high concentrations of $\mathrm{C}_{2} \mathrm{H}_{2}(10-20 \%, \mathrm{v} / \mathrm{v})$ in the gas phase normally employed in the assay. As a result, products of metabolism normally utilized by methanogens (i.e. $\mathrm{H}_{2}, \mathrm{CO}_{2}$, acetate or formate) may possibly accumulate to levels inhibitory to $\mathrm{N}_{2}$-fixing microbes. It is known that nitrogenase is inhibited competitively by $\mathrm{H}_{2}$, showing $50 \%$ inhibition at $11 \%(\mathrm{v} / \mathrm{v}) \mathrm{H}_{2}(\mathrm{Hwang}$ et al., 1973), and that weak acids such as acetate may uncouple energy conservation (Kell et al., 1981 b).

Most of the reports dealing with $\mathrm{C}_{2} \mathrm{H}_{2}$ inhibition (see Introduction) have employed $\mathrm{C}_{2} \mathrm{H}_{2}$ concentrations of about $10 \%(\mathrm{v} / \mathrm{v})$ to assess the validity of the acetylene reduction method. Some of these inhibitions require high $\mathrm{C}_{2} \mathrm{H}_{2}$ concentrations. For example, growth of $C$. pasteurianum, repressed for nitrogenase activity, was inhibited by $10 \%(\mathrm{v} / \mathrm{v}) \mathrm{C}_{2} \mathrm{H}_{2}$ (Brouzes \& Knowles, 1971), but not by $0.91 \%$ (this study). Methanogens (Raimbault, 1975; this study) and Nitrosomonas europaea (Hynes \& Knowles, 1978) appear unusual in their susceptibility to low concentrations of $\mathrm{C}_{2} \mathrm{H}_{2}$. Growth of Methanosarcina barkeri is inhibited by $\mathrm{C}_{2} \mathrm{H}_{2}$ (Raimbault, 1975), although this organism was the least sensitive (Table 4) of several methanogens tested.

Mr R. Latta, of the NRCC culture collection, provided pure cultures of the non-methanogenic bacteria used in this study. This paper is NRCC no. 20171.

\section{REFERENCES}

Balderston, W. L., Sherr, B. \& Payne, W. J. (1976).

Blockage by acetylene of nitrous oxide reduction in Pseudomonas perfectomarinus. Applied and Environmental Microbiology 31, 504-508.

DE BonT, J. A. M. \& Mulder, E. G. (1976). Invalidity of the acetylene reduction assay in alkane-utilizing, nitrogen-fixing bacteria. Applied and Environmental Microbiology 31, 640-647.

Bothe, H., TenNigkeit, J. \& EisbrenNeR, G. (1977). The utilization of molecular hydrogen by the blue- 
green alga Anabaena cylindrica. Archives of Microbiology 114, 43-49.

Breuil, C. \& Patel, G. B. (1980). Composition of Methanospirillum hungatei GP1 during growth on different media. Canadian Journal of Microbiology 26 , $577-582$.

Brouzes, R. \& KNowles, R. (1971). Inhibition of growth of Clostridium pasteurianum by acetylene : implication for nitrogen fixation assay. Canadian Journal of Microbiology 17, 1483-1489.

Chan, Y. K., Nelson, L. M. \& Knowles, R. (1980). Hydrogen metabolism of Azospirillum brasiliense in nitrogen-free medium. Canadian Journal of Microbiology 26, 1126-1131.

Cohen, G. N. \& Rickenberg, H. V. (1956). Concentration spécifique réversible des amino acides chez Escherichia coli. Annales de l'Institut Pasteur 91, 693-720.

Crane, R. K. \& Lipmann, F. (1953). The effect of arsenate on aerobic phosphorylation. Journal of Biological Chemistry 201, 235-243.

Diekert, G., Weber, B. \& Thauer, R. K. (1980). Nickel dependence of factor $F_{430}$ content in Methanobacterium thermoautotrophicum. Archives of Microbiology 127, 273-278.

Doddema, H. J., Hutten, T. J., Van Der DRIFT, C. \& VoGeLs, G. D. (1978). ATP hydrolysis and synthesis by the membrane-bound ATP synthetase complex of Methanobacterium thermoautotrophicum. Journal of Bacteriology 136, 19-23.

ELLEFSON, W. L. \& Wolfe, R. S. (1980). Role of component $\mathrm{C}$ in the methylreductase system of Methanobacterium. Journal of Biological Chemistry 255, 83888389.

Elleway, R. F., Sabine, J. R. \& Nicholas, D. J. D. (1971). Acetylene reduction by rumen microflora. Archives of Microbiology 76, 277-291.

Flett, R. J., Hamilton, R. D. \& Campbell, N. E. R. (1976). Aquatic acetylene-reduction techniques: solutions to several problems. Canadian Journal of Microbiology 22, 43-51.

Gunsalus, R. P. \& WolfE, R. S. (1980). Methyl coenzyme $\mathrm{M}$ reductase from Methanobacterium thermoautotrophicum. Journal of Biological Chemistry 255, 1891-1895.

Gunsalus, R. P., Romesser, J. A. \& Wolfe, R. S. (1978). Preparation of coenzyme $\mathbf{M}$ analogues and their activity in the methyl coenzyme $M$ reductase system of Methanobacterium thermoautotrophicum. Biochemistry 17, 2374-2377.

Hwang, J. C., Chen, C. H. \& Burris, R. H. (1973). Inhibition of nitrogenase-catalyzed reductions. Biochimica et biophysica acta 292, 256-270.

HYNES, R. K. \& KNOWLES, R. (1978). Inhibition by acetylene of ammonia oxidation in Nitrosomonas europaea. FEMS Microbiology Letters 4, 319-321.

Jarrell, K. F. \& SprotT, G. D. (1981). The transmembrane electrical potential and intracellular $\mathrm{pH}$ in methanogenic bacteria. Canadian Journal of Microbiology 27, 720-728.

JARRELl, K. F., Colvin, J. R. \& SPROTT, G. D. (1982) Spontaneous protoplast formation in Methanobacterium bryantii. Journal of Bacteriology 149, 346 353.

Kell, D. B., Doddema, H. J., Morris, J. G. \& VoGELS, G. D. $(1981 a)$. Energy coupling in methanogens. In Proceedings of the 3rd International Sym- posium on Microbial Growth on C-1 Compounds, pp. 159-170. Edited by H. Dalton. London: Heyden \& Sons.

Kell, D. B., Peck, M. W., Rodger, G. \& Morris, J. G. $(1981 b)$. On the permeability to weak acids and bases of the cytoplasmic membrane of Clostridium pasteurianum. Biochemical and Biophysical Research Communications 99, 81-88.

LAMberT, G. R. \& SMITH, G. D. (1980). Hydrogen metabolism by filamentous cyanobacteria. Archives of Biochemistry and Biophysics 205, 36-50.

MacGregor, A. N. \& KeENEY, D. R. (1973). Methane formation by lake sediments during in vitro incubation. Water Resource Bulletin 9, 1153-1158.

McKellar, R. C., Shaw, K. M. \& Sprott, G. D. (1981). Isolation and characterization of a FADdependent NADH diaphorase from Methanospirillum hungatei strain GP1. Canadian Journal of Biochemistry 59, 83-91.

MitCHELl, P. (1975). Proton translocation mechanisms and energy transduction by adenosine triphosphatases: an answer to criticisms. FEBS Letters 50, 95-97.

MOUNTFORT, D. O. (1978). Evidence for ATP synthesis driven by a proton gradient in Methanosarcina barkeri. Biochemical and Biophysical Research Communications 85, 1346-1351.

OREMLAND, R. S. \& TAYLOR, B. F. (1975). Inhibition of methanogenesis in marine sediments by acetylene and ethylene: validity of the acetylene reduction assay for anaerobic microcosms. Applied Microbiology 30, 707-709.

Patel, G. B. \& AGNew, B. J. (1981). A simple apparatus for measuring the $E_{\mathrm{h}}$ of anaerobic media. Canadian Journal of Microbiology 27, 853-855.

PRASAD, I. \& SCHAEFLER, S. (1974). Regulation of the $\beta$ glucoside system in Escherichia coli K-12. Journal of Bacteriology 120, 638-650.

RaImbault, M. (1975). Étude de l'influence inhibitrice de l'acétylène sur la formation biologique de méthane dans un sol de rizière. Annals Microbiologique (Institute Pasteur) 126A, 247-258.

Sauer, F. D., Erfle, J. D. \& Mahadevan, S. (1981). Evidence for an internal electrochemical proton gradient in Methanobacterium thermoautotrophicum. Journal of Biological Chemistry 256, 9843-9848.

Saunders, G. F., Campbell, L. L. \& Postgate, J. R. (1964). Base composition of deoxyribonucleic acid of sulfate-reducing bacteria deduced from buoyant density measurements in cesium chloride. Journal of Bacteriology 87, 1073-1078.

Schönheit, P., Moll, J. \& Thauer, R. K. (1979). Nickel, cobalt, and molybdenum requirement for growth of Methanobacterium thermoautotrophicum. Archives of Microbiology 123, 105-107.

SEghal, S. N. \& Gibbons, N. E. (1960). Effect of some metal ions on the growth of Halobacterium cutirubrum. Canadian Journal of Microbiology 6, 165-169.

SMITH, L. A., Hill, S. \& YATES, M. G. (1976). Inhibition by acetylene of conventional hydrogenase in nitrogen-fixing bacteria. Nature, London 262, 209210.

SPENCER, R. W., DANIELS, L. \& ORME-Johnson, W. H. (1980). Product isotope effects on in vivo methanogenesis by Methanobacterium thermoautotrophicum. Biochemistry 19, 3678-3683.

Sprott, G. D., Colvin, J. R. \& McKellar, R. C. 
(1979). Spheroplasts of Methanospirillum hungatii formed upon treatment with dithiothreitol. Canadian Journal of Microbiology 25, 730-738.

SPROTT, G. D. \& JARRELL, K. F. (1981). $\mathrm{K}^{+}, \mathrm{Na}^{+}$, and $\mathrm{Mg}^{2+}$ content and permeability of Methanospirillum hungatei and Methanobacterium thermoautotrophicum. Canadian Journal of Microbiology 27, 444451.

Wilson, D. M., Alderete, J. F., Maloney, P. C. \& WILSON, T. H. (1976). Protonmotive force as the source of energy for adenosine 5'-triphosphate synthesis in Escherichia coli. Journal of Bacteriology 126, 327-337.

Woese, C. R., Magrum, L. J. \& Fox, G. E. (1978). Archaebacteria. Journal of Molecular Evolution 11, 245-252.
Yamazaki, S., Tsai, L. \& Stadtman, T. C. (1980). Stereochemical studies of 8-hydroxy-5-deazaflavindependent $\mathrm{NADP}^{+}$reductase from Methanococcus vannielii. Journal of Biological Chemistry 255, 90259027.

YoshinaRI, T. \& KNowles, R. (1976). Acetylene inhibition of nitrous oxide reduction by denitrifying bacteria. Biochemical and Biophysical Research Communications 69, 705-710.

Zehnder, A. J. B., Huser, B. A., Brock, T. D. \& WuHRMANN, K. (1980). Characterization of an acetate-decarboxylating, non-hydrogen-oxidizing methane bacterium. Archives of Microbiology 124, $1-11$. 